\title{
Identifying Knowledge Enablers in Organizational Visions: A Synthesis of Theory and Practice
}

\author{
Florian Kragulj \\ Vienna University of Economics \\ and Business \\ Austria \\ florian.kragulj@wu.ac.at
}

\author{
Alexander Kaiser \\ Vienna University of Economics \\ and Business \\ Austria \\ alexander.kaiser@wu.ac.at
}

\author{
Thomas Grisold \\ Vienna University of Economics \\ and Business \\ Austria \\ thomas.grisold@wu.ac.at
}

\begin{abstract}
Despite ongoing interest in organizational visions, both in research and practice, there is little understanding of what a vision should entail. What makes a good vision? We approach this question from a knowledge perspective and explore what organizations need to know in order to effectively plan and perform organizational activities. We will review relevant literature and conduct a content analysis of visions of global profit-oriented organizations. By providing a synthesis of theory and practice, we suggest that organizational visions should include three knowledge enablers, which guide the creation as well as the management of (1) knowledge about organizational identity, (2) knowledge about mutual embeddedness, and (3) knowledge about emerging opportunities. Our findings can contribute to research on vision development and vision content. Furthermore, they can inform a recent discussion in the $\mathrm{KM}$ community to guide $\mathrm{KM}$ activities in organizations.
\end{abstract}

\section{Introduction}

'The past is history, and the future is a mystery' - this popular adage captures nicely the tension in an organization when it takes decisions and plans prospective actions. On the one hand, an organization relies on past experiences by drawing on best practices and avoiding previous sources of failure [1], [2]. On the other hand, since the future is not an extrapolation of the past, it has to be open and flexible enough for what might happen in the future [3]. Thus, an organization needs a flexible guideline or some abstract future image it can relate to.

One way to prepare organizations for their future is to implement and communicate a vision [4]. A vision can be seen as the picture of an ideal state in a distant future, which an organization is driven to achieve. It keeps employees and leaders "on the same page"; it motivates actors in the organization and provides competitive advantage by being attractive to and creating a collective identity with its followers [5]. There seems to be agreement on how a vision should look like. For example, Berson et al. [6, p. 144] argue that "effective vision statements tend to be relatively abstract, based on imagery, far-reaching and timeless", and they are "general and are never fully achieved in practice." Certainly, such attributes help to identify and form a vision. At the same time, going beyond general attributes, we face a more fundamental problem here. Since we are not able to predict what is going to happen the future, we have to assess what we should include today to ensure the relevance of the vision in an unknown future (say, in 20 years). Thus, before developing and implementing a vision in organizations, we have to identify what should be part of the vision so that the organization can take appropriate actions. What makes a strong organizational vision? This is the question we are addressing in this paper.

To do so, we take a knowledge perspective on visions. We seek to find out what knowledge of/about the organization is needed to create a vision. Findings can contribute to research on vision development and implementation as well as on vision content.

Generally speaking, research on visions covers a number of disciplines, such as psychology, leadership and management research, etc. They focus on different aspects and thus, research can lead to contradictory results [6]. In this paper, we will synthesize theoretical considerations from literature with a content analysis on how profit-oriented organizations (i.e. companies) design and realize their visions in practice. The motivation behind this approach is to avoid contradictions between what 'should be done from a theoretical point of view' and 'what is done in practice'[7].

This paper is structured as follows. We will begin with the theoretical background of organizational visions, laying our focus on a knowledge-related perspective on organizational visions. Subsequently, we will present a content analysis of visions of successful 
global profit-oriented organizations. In the findings section, we will synthesize the findings from theory and practice and develop what we refer to as "knowledge enablers" for visions.

Finally, we will point to implications. Here, we consider a recent discussion in the KM community and build on the recently revised Jennex Olfman Knowledge Success Model [8]. By introducing the concept of a "knowledge vision" - in addition to the "knowledge strategy" - our findings can drive the knowledge management activities in an organization before, during and after a vision development process.

\section{Theoretical background and research gap}

\subsection{Vision}

There are various definitions for the term "vision". Lukas states that a vision is an organizational charter of core values and principles, the headwater for priorities, plans and goals, a puller into the future, a determination and publication of what makes an organization unique, and a declaration of interdependence [9]. House and Shamir [10] assert that a vision is an ideal that represents the shared values in an organization.

Visions can be seen as "points of orientation" in that they are based on core values and shared perceptions [11]. Answers to profound questions, such as "What are our values?", "What is our mission?" and "What are our goals?" can lead to essential elements of a vision [12].

Furthermore, visions can be a source of motivation and coordination when they set groups of people in motion. Collins and Porras point out that a vision should be based on a vivid description of an envisioned future because organizations need "such a big commitment that when people see what the goal will take, there's an almost audible gulp" [13, p. 75].

In line with these considerations, Kantabutra et al. suggest that visions should be concise, clear, futureoriented, stable, challenging, abstract, and inspiring [14]. In a similar vein, O'Connell synthesizes various definitions of visions to argue that a vision is "an idealized goal state, a set of blueprints for the future, an agenda, a map for members to follow, and an image of what needs to be achieved. It may include both long-term, future-oriented goals and emotional appeals embedded in a set of values; it is focused on change and depicts a future that is credible, realistic, attractive, inspiring, and better than the status quo" [15, p. 105]. Therefore, a vision can be seen as a dialogue between the present and the future.

\section{What a vision is not}

At this point, it is crucial to delineate visions from seemingly related concepts.
A vision is not a high concept statement, a motto or adage, an advertising slogan, a strategy or plan, nor is it a view from the top or a review of the past [9].

A vision differs from an objective. It is the documented purpose that is detailed, customized, unique, and reasonable whereas an objective is a specific and product-oriented statement of an intended accomplishment that is attainable, observable, and measurable by specifying no more than the 'what', 'where', 'when' and 'how'. In contrast to an objective, a vision emphasizes the 'why'. A vision does not simply change, whereas plans, objectives or even strategies remain flexible and can be subject to change [16].

To sum up, we define a "vision" in the following way:

A vision is a clear and purposeful image of a fulfilling and desirable future which can be described to others and which is possible to be realized in any maybe extremely challenging - way, shape or form.

\subsection{Vision development}

Generally speaking, there are four ways in which a vision can be developed [15]: (1) A leader creates a vision, (2) a leader and a group of top managers create a vision, (3) a leader and followers co-creatively develop a vision, and (4) a vision is developed when the organization as a whole engages in a collaborative development process.

When it comes to what should be developed in such a process, we will turn to four approaches which focus on visions under a knowledge and/or organizational learning perspective.

\section{Senge's model}

Perhaps one of the most popular approaches is by Peter Senge. He states that the development of a shared vision involves a number of skills [6, p.13f]: (1) encouraging personal vision, (2) communicating and asking for support, (3) visioning as an ongoing process, (4) blending extrinsic, and (5) intrinsic visions and distinguishing positive from negative visions.

At the same time, there needs to be a tension between the organizations' present and future because "creative tension comes from seeing clearly where we want to be, our 'vision', and telling the truth about where we are, our 'current reality'. The gap between the two generates a natural tension" [17]. However, Senge does not outline the vision development process per se. He does not suggest specific steps to be taken nor does he explain what should be part of a vision.

\section{Intentional Change Theory}

Another model that is strongly connected to vision 
development is the Intentional Change Theory (ICT) by Richard Boyatzis. It focuses on how to trigger sustainable change on the individual as well as on the organizational level. According to ICT, such a change process entails so-called "discoveries". There are five discoveries, namely (1) the ideal self and a (personal) vision, (2) the real self and its comparison to the ideal self, resulting in an assessment of one's strengths and weaknesses, (3) a learning agenda and plan, (4) experimentation and practice with new behavior, thoughts, feelings, and/or perceptions, and finally (5) trusting, or resonant relationships that enable a person to experience and process each discovery in the process [18].

While ICT has been originally developed for change processes on the individual level, ICT can be applied to organizational contexts to explain how organizations change and come up with new visions [19]. However, ICT does not specify what the vision should entail.

\section{Nonaka's approach}

Nonaka stresses the importance of a vision for the knowledge creating process in an organization. The so called "knowledge vision" is emphasized in the popular SECI model [20] as well as in his enhanced theory of the knowledge creating firm [21], [22]. Central is the idea that knowledge creation is a process of realizing one's vision of the future or personal belief through the practice of interaction with others and the environment [22]. Accordingly, his theory of organizational knowledge creation puts the development of knowledge visions in the foreground [23].

Nonaka et al. argue that a knowledge vision has to specify how an organization and its knowledge base, knowledge frame and knowledge dynamics should evolve in the long term [24]. They point out that the knowledge vision gives a direction for the knowledge creation process, and the resulting knowledge, that is, it defines what kind of knowledge the company should create in what domain as the knowledge vision. What a knowledge vision contains depends on fundamental questions, such as "What are we?", "What should we create?", "How can we do it?", "Why are we doing this?" and "Where are we going?" [25]. Furthermore, Nonaka emphasizes that a knowledge vision should transcend the boundaries of existing products, divisions, organizations and markets [24]. The knowledge vision also defines the value system that evaluates, justifies and determines the quality of the knowledge the company creates.

At the same time, Nonaka et al. do not provide details on what knowledge should be grounded in the company's overall vision.

\section{Theory Wave}

The theory Wave is a theoretical framework to describe the process of creating a vision in/for organizations [26]; it aims at shedding light on the process of developing a vision. It departs from the premise that vision development should be participatory, that is, members from all levels of an organization should be involved. Essentially, the theory covers three aspects that should be considered in a vision development process. First, organizations should learn from an envisioned future to imagine a future scenario which is ideal and fulfills the most inner dreams and wishes of actors in an organization. Second, a vision should consider the substantial needs that are shared among the members of an organization. Finally, the vision-development process should move along a wave-like process that includes three steps; (1) a provisional "vision-1" covering all wishes and ideas for an ideal future of the organization; (2) identifying the underlying needs of "vision-1"; (3) transforming and capturing of what is the essence of all members' needs in a sustainable vision.

A closer look at this theory does not reveal what a vision should actually consist of.

\subsection{Research gap}

Research focuses on different aspects of vision development. However, across theories and models, it remains unclear what elements should be actually developed and contained in a vision.

At this point, it is important to note that research uses the term "vision content". However, there is no consistent use of the term. For example, Kantrabutra and Avery [14] suggest that "vision content" refers to general features or guidelines that should be part of a vision (e.g. a vision should be brief, motivating and shared by all members). Baum et al. [27] argue that content refers to the general focus of an organization's business activities (e.g. growth), which is provided by the leader and his/her strategic goals. Others underline the role of the leader in communicating visions and their content effectively [28], [29].

We argue that the content of the vision should be understood as providing organizations with "capacities to act" towards a desired future, that is, they need to include what knowledge they need in order to realize a desired future [30], [31]. Thus, by taking a knowledge perspective on visions, we suggest to see the content of visions in terms of "knowledge enablers", which specify what an organization should realize over time, i.e. what capacities it needs in order to act effectively. Identifying and considering such knowledge enablers could be relevant for vision development and implementation. 
Based on this argument, we define the following research question:

What kinds of knowledge should be considered in an effective organizational vision when we synthesize theoretical arguments with manifestations in practice?

\subsection{Research method}

In order to reflect the relevance for both theory and practice, we will utilize two approaches. On the one hand, we build on the theoretical perspectives as considered in the previous section. Here, our focus lies on knowledge-related approaches on visions, including positions in knowledge management and organizational learning. On the other hand, we will perform a content analysis [32] of successful profitoriented organizations to analyze how organizations design visions in practice. Finally, we will suggest knowledge enablers which are in line with the theoretical state of the art and can be realized in practice.

\section{Analysis and findings}

In this section, we take an empirical take on visions that companies - i.e. organizations that are profitoriented - communicate to the public.

\subsection{Method and procedure}

To analyze visions of profit-oriented organizations, we conducted a qualitative content analysis [32], [33]. Using Krippendorff's [32] five questions for content analysis, we will outline the premises of our study.

What is the target of the inferences?

Our analysis analyzes the content of visions of leading companies. We look for common themes and patterns that are considered important across visions.

What is the population from which the sample is drawn?

We focus on visions from notable and successful profit-oriented organizations. We draw on random samples from three (global) indices that are regularly published by Forbes; (1) the biggest publicly owned companies, (2) the most innovative and expanding companies, and (3) the best small companies.

For the first category, we use the "Forbes Global 2000". It is an annual ranking of the top 2000 public companies in the world [34] $(n=2000$; index A, sample P1 - P10; cf. table 1) and it is based on four parameters: sales, profit, assets, and market value [35]. In order to investigate the most innovative and expanding companies, we use the "Most Innovative Growth Companies" index ( $\mathrm{n}=100$; index B; sample P11 - P20, cf. table 1), which is based on the companies' expected innovativeness [36].

And finally, we consider the "Best Small Companies" index $(\mathrm{n}=25$; index C; sample P21 - P30, cf. table 1) which lists small firms that stand out from others in their fields, and value the impact on their communities over growth. They have sound business models, strong balance sheets, and steady profits [37].

We randomly selected 10 organizations from each index. They are depicted in table 1.

\begin{tabular}{|c|c|c|c|c|}
\hline \# & \begin{tabular}{l} 
त्र \\
\multirow{2}{*}{} \\
$\#$
\end{tabular} & $\overbrace{0}^{0}$ & $\stackrel{\varrho}{E}$ & 音 \\
\hline P1 & A-0040 & Gazprom & Russia & Oil \& Gas Operations \\
\hline P2 & A-0066 & Prudential & UK & $\begin{array}{l}\text { Life \& Health } \\
\text { Insurance }\end{array}$ \\
\hline P3 & A-0127 & $\begin{array}{l}\text { Zurich } \\
\text { Insurance } \\
\text { Group }\end{array}$ & Switzerland & Diversified Insurance \\
\hline P4 & A-0139 & Iberdrola & Spain & Electric Utilities \\
\hline P5 & A-0289 & Accenture & Ireland & Computer Services \\
\hline P6 & A-0430 & $\begin{array}{l}\text { Baoshan Iron } \\
\& \text { Steel }\end{array}$ & China & Iron \& Steel \\
\hline P7 & A-0635 & $\begin{array}{l}\text { Sumitomo } \\
\text { Realty }\end{array}$ & Japan & Real Estate \\
\hline P8 & A-0728 & $\begin{array}{l}\text { WEC Energy } \\
\text { Group }\end{array}$ & US / Wisconsin & Electric Utilities \\
\hline P9 & A-1625 & AU Optronics & Taiwan & Electronics \\
\hline P10 & A-1754 & $\begin{array}{l}\text { International } \\
\text { Flavors \& } \\
\text { Fragrances }\end{array}$ & US & $\begin{array}{l}\text { Household/Personal } \\
\text { Care }\end{array}$ \\
\hline P11 & B-004 & Insulet Corp & $\begin{array}{l}\text { US / } \\
\text { Massachusetts }\end{array}$ & $\begin{array}{l}\text { Health Care Equipment } \\
\& \text { Services }\end{array}$ \\
\hline P12 & B-007 & $\begin{array}{l}\text { Ultimate } \\
\text { Software } \\
\text { Group }\end{array}$ & US / Florida & IT Software \& Services \\
\hline P13 & B-011 & $\begin{array}{l}\text { Acadia } \\
\text { Pharmaceutic } \\
\text { als }\end{array}$ & US / California & $\begin{array}{l}\text { Pharmaceuticals, } \\
\text { Biotechnology \& Life } \\
\text { Sciences }\end{array}$ \\
\hline P14 & B-025 & $\begin{array}{l}\text { Nihon M \& A } \\
\text { Center }\end{array}$ & Japan & $\begin{array}{l}\text { Commercial \& } \\
\text { Professional Services }\end{array}$ \\
\hline P15 & B-028 & $\begin{array}{l}\text { Tongfang } \\
\text { Guoxin } \\
\text { Electronics } \\
\end{array}$ & China & $\begin{array}{l}\text { Technology Hardware } \\
\text { \& Equipment }\end{array}$ \\
\hline P16 & B-032 & $\begin{array}{l}\text { Chongqing } \\
\text { Zhifei } \\
\text { Biological } \\
\text { Products } \\
\end{array}$ & China & $\begin{array}{l}\text { Pharmaceuticals, } \\
\text { Biotechnology \& Life } \\
\text { Sciences }\end{array}$ \\
\hline P17 & B-045 & $\begin{array}{l}\text { Ionis } \\
\text { Pharmaceutic } \\
\text { als }\end{array}$ & US / California & $\begin{array}{l}\text { Drugs \& } \\
\text { Biotechnology }\end{array}$ \\
\hline P18 & B-051 & $\begin{array}{l}\text { Godrej } \\
\text { Consumer } \\
\text { Products }\end{array}$ & India & $\begin{array}{l}\text { Household \& Personal } \\
\text { Products }\end{array}$ \\
\hline P19 & B-089 & $\begin{array}{l}\text { Swedish } \\
\text { Orphan } \\
\text { Biovitrum }\end{array}$ & Sweden & $\begin{array}{l}\text { Pharmaceuticals, } \\
\text { Biotechnology \& Life } \\
\text { Sciences }\end{array}$ \\
\hline P20 & B-099 & Abcam & UK & $\begin{array}{l}\text { Pharmaceuticals, } \\
\text { Biotechnology \& Life } \\
\text { Sciences }\end{array}$ \\
\hline P21 & C-03 & Dansko & $\begin{array}{l}\text { US / } \\
\text { Pennsylvania }\end{array}$ & Retailing \\
\hline P22 & C-04 & $\begin{array}{l}\text { Dutch Bros. } \\
\text { Coffee }\end{array}$ & US / Oregon & $\begin{array}{l}\text { Food, Drink \& } \\
\text { Tobacco }\end{array}$ \\
\hline P23 & C-06 & FreshBooks & US / Ontario & IT Software \& Services \\
\hline P24 & C-07 & Fusion OEM & US / Illinois & Manufacturing \\
\hline $\mathrm{P} 25$ & C-11 & HED Cycling & US / Minnesota & Manufacturing \\
\hline P26 & C-17 & OnceLogix & US / N. Carolina & $\begin{array}{l}\text { Health Care Equipment } \\
\& \text { Svcs }\end{array}$ \\
\hline P27 & $\mathrm{C}-20$ & Rhino Foods & US / Vermont & Food Markets \\
\hline P28 & $\mathrm{C}-21$ & SRC holdings & US / Missouri & Manufacturing \\
\hline P29 & $\mathrm{C}-22$ & $\begin{array}{l}\text { StickerGiant. } \\
\text { com }\end{array}$ & US / Colorado & Manufacturing \\
\hline P30 & $\mathrm{C}-24$ & Turnerboone & US / Georgia & Retailing \\
\hline
\end{tabular}

Table 1: Randomly drawn sample of 30 companies 
Which data are analyzed? How are they defined?

Given the set of 30 randomly selected companies (P1 - P30; cf. table 1), we searched their corporate websites for vision statements (or closely related statements).

Our search was double-staged. First, we visited the (international) cooperate websites and browsed through them. If we could not find the vision on the website, we performed a Google search (from Europe and in browser privacy mode to reduce predictions of the search algorithm as possible, e.g. cookies). The search string reads as 'site:URL vision'.

What is the context relative to which the data are analyzed?

We analyzed the data with respect to the theoretical findings and the presented definition of a vision (see section 2).

What are the boundaries of the analysis?

We used a limited sample of global companies to get a first understanding of how companies design their visions. While we searched for common characteristics across visions, we cannot generalize our findings to whole populations.

\subsection{Analysis}

To analyze the content of the visions, we followed an iterative coding strategy as suggested in grounded theory [38]. We continuously created memos to document the research process and to ensure a shared understanding of the emerging concepts.

Following our double-staged search approach, we identified 27 websites where we could easily find sections dedicated the company's identity (in some cases, this was found in the "About Us"-section).

Our analysis consisted of three coding rounds.

In the first coding round, we analyzed the 27 websites in three respects: we looked for the designated vision statements. Second, we identified related concepts (terms) which companies sometimes use when they refer to vision statements. Third, we re-analyzed the provided information and, by applying our proposed definition, we identified the companies' visions.

Eight companies published statements that they explicitly labeled as their visions (P4, P5, P11, P13, P20, P21, P23, P30). Four of these statements corresponded with our definition (P4, P11, P13, P23). However, in terms of focus, structure, and content, we classified five other statements as visions, although they were not labeled as such (P2, P9, P16, P18, P24). In total, we found nine vision statements in the sample. Table 2 depicts examples of such statements:

\begin{tabular}{|l|l|l|}
\hline & & \\
Statement & Yes & No \\
\hline $\begin{array}{l}\text { "Create beautiful, effective and adaptable } \\
\text { workspaces" (P30) }\end{array}$ & No & Yes \\
\hline $\begin{array}{l}\text { "We are also bringing together our passion } \\
\text { and purpose to make a difference through } \\
\text { our 'Good \& Green' approach to create a } \\
\text { more inclusive and greener India." (P18) }\end{array}$ & & \\
\hline $\begin{array}{l}\text { "[...] helping people living with diabetes by } \\
\text { providing greater access to the data they } \\
\text { need to make smart and effective decisions } \\
\text { to better manage and control their disease" } \\
\text { (P11) }\end{array}$ & Yes & Yes \\
\hline
\end{tabular}

Table 2: Example statements from the content analysis and their classification

In the second coding round, we further investigated all vision statements that we identified in the nine websites (P2, P4, P9, P11, P13, P16, P18, P23, P24). In an in-depth analysis, we searched for distinct content artefacts within these statements and found 35 artefacts (codes).

In the third coding round, we searched for patterns emerging from the code set. In line with our research question, we focused on characteristics (in terms of content) that are found across visions and which point to the kinds of knowledge that should be enabled according to these visions.

To sum up, from 30 randomly selected companies, three companies (P14, P15, P22) did not publish any information (in English). We excluded cases, where companies only provide information on their identity (e.g. the company's history, values, principles), as this does not correspond to our definition of a vision. As a result, the visions of 9 companies were included in our analysis.

We found that the term "vision" was inconsistently used, and vision statements were often synonymously labeled as "mission" (P1, P3, P4, P6, P9, P12, P13, P16, P17), "history" (P13, P18, P21, P27, P28, P29, P30), "(core) values" (P2, P6, P13, P24), "(guiding) principles" (P27, P28), "culture" (P12, P17), "strategy" (P16), "purpose" (P19, P27), "(quality) policy" (P9), "capabilities" (P6), "competitive advantage" (P9), "heritage" (P3). And vice versa, what companies offered as their vision was in many cases not a vision.

\subsection{Results}

Our content analysis provided five content domains that are covered in the vision statements. We describe these five content domains in the following and give an overview in figure 1. 


\section{Customers}

In their vision statements, companies focus on their customers and emphasize customer value. Companies strive for providing customers with what they need. On this account, we found statements, such as "to help our customers achieve financial prosperity and peace of mind" (P2).

\section{Stakeholders}

Companies acknowledge that their actions have an impact on people inside and outside the organization. Companies seek to cooperate with their partners and build trustful relations. An example is, "[we want to] be[ing] the backbone to cooperate with [and] compete with multinational counterparts [...]" (P16). There is a strong focus on employees as particularly important stakeholders.

\section{Environment and society}

Companies consider that they have an impact on society and environment. In that regard, some visions claim to shape the future in a positive way, by addressing issues like human health, the common good, education and sustainability. Statements to illustrate this domain are to "become the driver of green industry" (P6) or "[we] invest[s] in the environment, health and education" (P18).

\section{Industry leadership and innovation}

Companies want to be pioneers in their domains. They strive for economic growth and increase in value (e.g. "We want to be the leading multinational group in the energy sector at the forefront of a better future, sustainably creating value with a quality service for people" (P4)). Innovation is seen as the key for staying flexible and having the lead on the market (e.g. "[we are a] provider of innovative solutions for growing and protecting wealth" (P2)).

\section{Company's self-conception}

Companies focus on their inner mechanisms and what drives their actions. On this account, visions emphasize the impact of shared values on their behavior. The company's self-conception is often backed by their presented history and genesis. Two statements shall exemplarily reflect this domain: "our history is rooted in science and strong leadership in CNS research" (P13) and "we are also bringing together our passion and purpose to make a difference $[\ldots] "(\mathrm{P} 18)$.

\begin{tabular}{|l|l|}
\hline \multicolumn{2}{|l|}{ Content domains of visions } \\
\hline customers & $\begin{array}{l}\text { enable customers' decision making } \\
\text { make customers' life easier } \\
\text { substantially improve customers' life } \\
\text { customer needs }\end{array}$ \\
\hline stakeholders & $\begin{array}{l}\text { international cooperations } \\
\text { trustful relationships } \\
\text { employees' well-being }\end{array}$ \\
\hline environment and society & $\begin{array}{l}\text { positive stance on the future } \\
\text { contribute to the health of humans } \\
\text { "green" focus } \\
\text { common good } \\
\text { education }\end{array}$ \\
\hline industry leadership and innovation & $\begin{array}{l}\text { continuous innovation } \\
\text { being in leading position } \\
\text { flexibility on market } \\
\text { being a role model }\end{array}$ \\
\hline company's self-conception & $\begin{array}{l}\text { value-driven } \\
\text { purpose } \\
\text { history } \\
\text { self reflection }\end{array}$ \\
\hline
\end{tabular}

Figure 1: Five content domains identified

\section{Findings: Knowledge enablers for realizing organizational visions}

So far, we have been looking at theoretical positions in vision research as well as on the actual use of visions in practice. Finally, by synthesizing the content domains from our study with our findings in the theoretical background, we provide three "knowledge enablers". They are depicted in figure 2.

Knowledge enablers ensure that an organization take actions that correspond to what the organization should achieve, why this is relevant for the organization, and how the organization should act and behave.

\section{Knowledge about organizational identity}

This enabler refers to the self-conception of the organization, that is, who it is and who it wants to be.

With respect to our study, this enabler emerges from the content domains "company's self-conception" and "industry leadership and innovation".

With reference to theory, this enabler reflects Nonaka et al.'s [25] claim that organizations should reflect on questions, such as "What are we?" and "Why are we doing this?". In that regard, this enabler aims at defining and reflecting the core of the organization. Accordingly, the knowledge, which is enabled here, shapes the organization's distinctiveness in terms of purpose and values; it involves knowledge about substantial needs as proposed by the Theory Wave [26] and the idea of personal mastery by Senge [6]. 


\section{Knowledge about mutual embeddedness}

This enabler refers to the context and the environment in which an organization is embedded, that is, anything that surrounds the organization.

This enabler emerges from the content domains "customers", "stakeholders", and "environment and society".

As literature stresses, organizations need to know how they relate to their environment and understand the dynamics of resulting dependencies. This does not only require the organization to identify its stakeholders and their characteristics, but also to become aware of the impact it has on the environment and the society. This enabler considers the third discovery in theory Wave, that is, the transformation of substantial needs into a viable vision [26] as well as the second and fourth discovery in the Intentional Change Theory [18], [19].

\section{Knowledge about emerging opportunities}

This knowledge enabler can be seen as the most challenging to create as it adds a future dimension.

As discussed in the theory part, organizations face uncertainty because the future is unpredictable. The first two knowledge enablers underline that organizations need to ensure who they are and how they interact with their environment. This enabler highlights that organizations need to grow and develop. Knowledge about emerging opportunities implies that organizations need to be able to perceive and interact with the environment such that they recognize opportunities for finding new manifestations of their identity [39]. The challenging aspect is to imply how an organization should develop without knowing what is going to happen and how future occurrences fit to the activities of an organization (say, through new business opportunities).

With respect to theory, this knowledge encompasses understanding of the ideal self (cf. Intentional Change Theory [18]) and provides orientation and motivation towards the envisioned future state (cf. phronesis [22]). A similar approach to this knowledge enabler is the "self-transcending knowledge" [40].

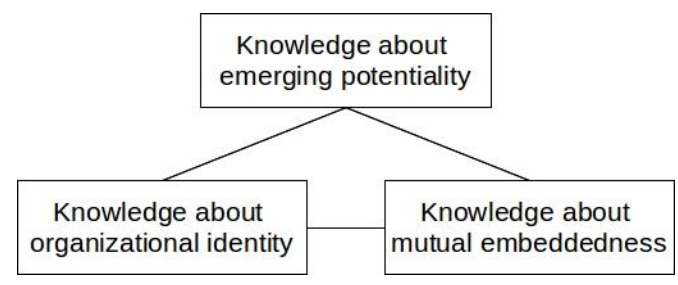

Figure 2: Three knowledge enablers

\section{Implications for knowledge management in organizations}

How can we ground these enablers such that organizations ensure that the needed knowledge is created over time? How can we ensure that these enablers come into effect? In the following, we will draw on a recent discussion in $\mathrm{KM}$ to argue that the most important implications for KM in organizations are the "KM strategy" and the "KM vision". Furthermore, we point to the learning dynamics that are needed to realize an effective vision.

\subsection{KM strategy}

In a recent paper, Jennex [8] re-examines the "Jennex Olfman Knowledge Management Success Model" [41] to suggest that an organization needs an effective strategy to coordinate its knowledge management activities. Furthermore, he places a stronger focus on leadership and governance to ensure that KM activities are aligned within the organization [8].

While the overall business strategy guides the activities of an organization as a whole, the KM strategy serves to allocate knowledge resources so that organizational goals can be met. It needs to produce tangible results [42] and it should address a variety of issues. First, it points to the knowledge resources that should be utilized [43], and it identifies knowledge content, its representation strategy, and how it is stored [8]. Second, the KM strategy clarifies the role that knowledge will play in value creation [43]. Third, it provides a link to business objectives and coordinates short-term and long-term initiatives and benefits [43]. Fourth, a KM strategy aligns KM initiatives with the organization's competitive strategy, and it identifies KM metrics, key knowledge users, and incentives needed to ensure knowledge use [8].

\subsection{KM vision}

Since a strategy specifies activities to realize a vision, it is dependent on and derived from a vision. Thus, we can argue that a KM strategy needs to be derived from a "KM vision". Following this claim, a $\mathrm{KM}$ vision must be built on the current status of an organization to provides a direction for $\mathrm{KM}$ activities in an organization [44]. A KM vision offers a roadmap to integrate KM strategy with the strategy of the organization [44]. Thus, it can be seen as an important link between the company's vision, organization, and the unique characteristics of the KM activities in order to identify and work within and towards the purpose, vision and values of the company [45]. 
In short, we can argue that the company's vision determines what we call the "KM vision" as well as the company's strategy and the KM strategy. The KM vision can be seen as providing the central link. This is shown in figure 3.

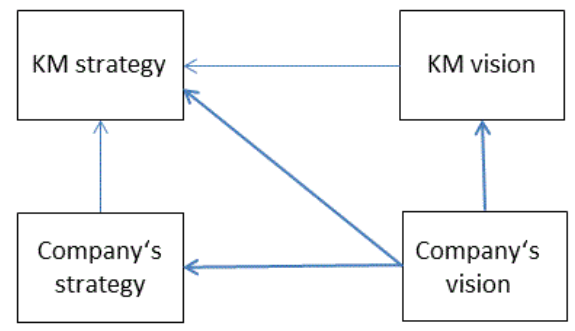

Figure 3: Implications for KM

For this reason, it seems crucial to consider the three proposed knowledge enablers knowledge about organizational identity, knowledge about mutual embeddedness, and knowledge about emerging opportunities explicitly in the KM vision. On the one hand, this enables an organization to allocate the knowledge resources to the goals of an organization. In that respect, it is sustainable and can serve as an action guiding basis for an efficient strategic planning process for both the business strategy and the $\mathrm{KM}$ strategy. On the other hand, a KM strategy can be an important aspect for the KM success in general. Building on the re-examined Jennex Olfman Knowledge Success Model, it constitutes an approach to enhance the system quality dimension with the constructs "KM vision" and "company's vision"; this is depicted in figure 4.

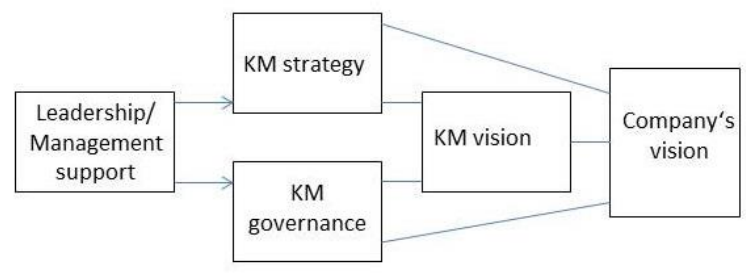

Figure 4: Enhanced system quality dimension

\subsection{Learning and unlearning in vision pursuit}

As argued before, the challenge in organizational growth lies in the unpredictability of the future. The knowledge enablers here are broad in the sense that they are open for interpretation. What knowledge about mutual embeddedness means in a present context can be radically different at some later point in time. Certainly, directing knowledge and learning activities with respect to the vision requires an organization to learn and create new knowledge at different levels [46]. At the same time, when an organization faces conditions that are incompatible with their existing knowledge, they might need to "unlearn" [47], [48]. How effective learning and unlearning processes look like in practice depends on both the organization and the environment it has to cope with. However, organizations need to be aware that vision pursuit is not a linear process that simply enfolds over time. It might require questioning best practices, getting rid of well-proven solutions, and reducing the influence of old knowledge structures (such as triggers and environmental cues) on the cognitive and behavioural activities of the members [49] so that new and appropriate knowledge can be created. Successfully pursuing the realization of the knowledge enablers in a vision can be complex and may evoke states of uncertainty.

\section{Conclusion}

\subsection{Summary}

Visions can be seen as driving forces for organizations to achieve some desirable future state. However, there is no agreement on what needs to be known in order to reach this future state. To address this gap and to explore what strong visions should contain, we reviewed major theories focusing on knowledgeaspects of visions. Furthermore, we performed a content analysis of global profit-oriented organizations to see how they realize their visions; we analyzed visions of successful companies that were randomly selected from three Forbes indices.

Synthesizing positions from literature with our findings from the content analysis, we conceptualized three "knowledge enablers" that should be considered when developing a vision; (1) knowledge about organizational identity, (2) knowledge about mutual embeddedness and (3) knowledge about emerging opportunities. Finally, we suggested how these knowledge enablers can be grounded in the KM activities of an organization. Our results provide interesting contributions for theory and practice, in particular for research on vision development and implementation as well as on vision content.

\subsection{Limitations and future research}

There are some limitations which should be addressed in future research.

First, we could only use a limited sample size for our content analysis. This is for two reasons. On the one hand, we selected a small sample size of 30 companies for our analysis. However, more importantly, during our research we found that theory and practice have different views on what a vision is. We had to exclude a number of companies because they did not suggest a vison but some other information on their identity. 
Second, we focused on visions of companies. Arguably, when considering visions of non-profit oriented organizations, we might get different results. For example, economic growth and innovativeness could play a less significant role here. Furthermore, we selected the companies from Forbes, i.e. a US-based report. The sample can lead to a cultural bias of selected companies.

Finally, it seems interesting to see how vision pursuit contributes to other organizational phenomena, such as organizational change [50] and organizational becoming [51].

\section{References}

[1] J. Sydow, G. Schreyögg, and J. Koch, "Organizational Path Dependence: Opening the Black Box," Acad. Manag. Rev., vol. 34, no. 4, pp. 689-709, 2009.

[2] G. Schreyogg, J. Sydow, and P. Holtmann, "How history matters in organisations: The case of path dependence," Manag. Organ. Hist., vol. 6, no. 1, pp. 81-100, Feb. 2011.

[3] I. Buchen, "Creating the future: innovation and the unlearning organization," Foresight, vol. 1, no. 2, pp. 117-123, 1999.

[4] D. Stam, R. G. Lord, D. van Knippenberg, and B. Wisse, "An Image of Who We Might Become: Vision Communication, Possible Selves, and Vision Pursuit," Organ. Sci., vol. 25, no. 4, pp. 1172-1194, Aug. 2014.

[5] J. C. Kohles, M. C. Bligh, and M. K. Carsten, "A follower-centric approach to the vision integration process," Leadersh. Q., vol. 23, no. 3, pp. 476-487, 2012.

[6] Y. Berson, N. Halevy, B. Shamir, and M. Erez, "Leading from different psychological distances: A construal-level perspective on vision communication, goal setting, and follower motivation," 2014.

[7] P. Bansal, S. Bertels, T. Ewart, P. MacConnachie, and J. O'Brien, "Bridging the Research-Practice Gap," Acad. Manag. Perspect., vol. 26, no. 1, pp. 73-92, Feb. 2012.

[8] M. E. Jennex, "Re-Examining the Jennex Olfman Knowledge Management Success Model," in Proceedings of the 50th Hawaii International Conference on System Sciences, 2017, pp. 4375-4384.

[9] J. R. Lucas, "Anatomy of a vision statement," Management Review, vol. 87, no. 2. pp. 22-26, 1998.

[10] R. J. House and B. Sharmi, "Toward the integration of transformational, charismatic and visionary theories of leadership," in Leadership theory and research: Perspectives and directions, San Diego, CA: Academic Press, 1993, pp. 81-107.

[11] M. Dierkes, "Visions, Technology, and Organizational Knowledge," in Knowledge Management in the Innovation Process, Boston: Springer, 2001, pp. 9-42.

[12] J. V. Quigley, "Vision: How leaders develop it, share it, and sustain it," Bus. Horiz., vol. 37, no. 5, pp. 37-41, 1994.

[13] J. Collins and J. Porras, "Building Your Company's Vision," Harv. Bus. Rev., vol. 74, no. 5, pp. 65-77, 1996.

[14] S. Kantabutra and G. C. Avery, "The power of vision: statements that resonate," J. Bus. Strategy, vol. 31, no. 1, pp. 37-45, 2010.

[15] D. O'Connell, K. Hickerson, and a. Pillutla, "Organizational Visioning: An Integrative Review," Gr. Organ. Manag., vol. 36, pp. 103-125, 2011.

[16] J. Kim and T. Oki, "Visioneering: An essential framework in sustainability science," Sustain. Sci., vol. 6, pp. 247-251, 2011.

[17] P. M. Senge, "The Leader's New Work: Building Learning Organizations," Sloan Manage. Rev., vol. 32, no. 1, pp. 7-23, 1990.

[18] R. E. Boyatzis, "An overview of intentional change from a complexity perspective," J. Manag. Dev., vol. 25, no. 7, pp. 607-623, Aug. 2006.

[19] E. B. Van Oosten, "Intentional change theory at the organizational level: a case study," J. Manag. Dev., vol. 25, no. 7, p. 707, 2006.

[20] I. Nonaka, "A Dynamic Theory of Organizational Knowledge Creation," Organ. Sci., vol. 5, no. 1, pp. 14-37, Feb. 1994.

[21] I. Nonaka and R. Toyama, "The theory of the knowledge-creating firm: subjectivity, objectivity and synthesis," Ind. Corp. Chang., vol. 14, no. 3, pp. 419436, 2005.

[22] I. Nonaka and R. Toyama, "Strategic management as distributed practical wisdom (phronesis)," Ind. Corp. Chang., vol. 16, no. 3, pp. 371-394, 2007.

[23] I. Nonaka, G. von Krogh, and S. Voelpel, "Organizational Knowledge-Creation Theory: Evolutionary Paths and Future Advances," Organ. Stud., vol. 27, no. 8, pp. 1179-1208, 2006.

[24] I. Nonaka, R. Toyama, and A. Nagata, "A Firm as a Knowledge-creating Entity: A New Perspective on the Theory of the Firm," Ind. Corp. Chang., vol. 9, no. 1, pp. 1-20, 2000.

[25] I. Nonaka, R. Toyama, and N. Konno, "SECI, $\mathrm{Ba}$ and Leadership: a Unified Model of Dynamic 
Knowledge Creation," Long Range Plann., vol. 33, no. 1, pp. 5-34, Feb. 2000.

[26] A. Kaiser, "Towards a Knowledge-based Theory of Developing Sustainable Visions: The Theory Wave," in Proceedings of the 50th Hawaii International Conference on System Sciences, 2017, pp. 4495-4504.

[27] J. R. Baum, A. Locke, and S. A. Kirkpatrick, "A Longitudinal Study of the Relation of Vision and Vision Communication to Venture Growth in Entrepreneurial Firms," J. Appl. Psychol., vol. 83, no. 1, pp. 43-54, 1998.

[28] R. Awamleh and W. L. Gardner, "Perceptions of leader charisma and effectiveness: The effects of vision content, delivery, and organizational performance," Leadersh. Q., vol. 10, no. 3, pp. 345-373, 1999.

[29] J. J. Sosik and S. L. Dinger, "Relationships between leadership style and vision content: The moderating role of need for social approval, selfmonitoring, and need for social power," Leadersh. Q., vol. 18, no. 2, pp. 134-153, Apr. 2007.

[30] P. M. De Holan, N. Phillips, and T. B. Lawrence, "Managing Organizational Forgetting," MITSloan Manag. Rev., vol. 45, no. 2, pp. 45-51, 2004.

[31] K.-E. Sveiby, "A knowledge-based theory of the firm to guide in strategy formulation," J. Intellect. Cap., vol. 2, no. 4, pp. 344-358, 2001.

[32] K. Krippendorff, Content analysis. An introduction to its methodology, 3rd ed. Los Angeles: Sage, 2013.

[33] P. Mayring, Qualitative Content Analysis. Theoretical Foundation, Basic Procedures and Software Solution. Klagenfurt: Beltz, 2014.

[34] Forbes, "The World's Biggest Public Companies List," Forbes, 2017. [Online]. Available: https://www.forbes.com/global2000/list/\#tab:overall. [Accessed: 13-Jun-2017].

[35] A. Murphy, “2017 Global 2000 Methodology: How We Crunch the Numbers," Forbes, 2017. [Online]. Available: https://www.forbes.com/sites/andreamurphy/2017/05 /24/2017-global-2000-methodology-how-we-crunchthe-numbers/\#383dd6f61d41. [Accessed: 13-Jun$2017]$.

[36] Forbes, “The World's Most Innovative Growth Companies List," 2017. [Online]. Available: https://www.forbes.com/growth-companies/list/. [Accessed: 13-Jun-2017].

[37] Forbes, "Forbes Best Small Companies List," 2017. [Online]. Available: https://www.forbes.com/best-smallcompanies/list/\#tab:overall. [Accessed: 13-Jun-2017]. [38] K. Charmaz, Constructing Grounded Theory, 2nd ed. London: Sage, 2014.

[39] G. T. Lumpkin and B. B. Lichtenstein, "The Role of Organizational Learning in the OpportunityRecognition Process," Entrep. Theory Pract., vol. 29, no. 4, pp. 451-472, Jul. 2005.

[40] O. Scharmer, "Self-transcending knowledge: sensing and organizing around emerging opportunities," J. Knowl. Manag., vol. 5, no. 2, pp. 137-151, 2001.

[41] M. E. Jennex and L. Olfman, "A model of knowledge management success," Int. J. Knowl. Manag., vol. 2, no. 3, pp. 51-68, 2006.

[42] N. N. Sunassee and D. A. Sewry, "A Theoretical Framework for Knowledge Management Implementation," in Proceedings of SAICSIT 2002, 2002, pp. 235-245.

[43] M. du Plessis, "Knowledge management: what makes complex implementations successful?," $J$. Knowl. Manag., vol. 11, no. 2, pp. 91-101, 2007.

[44] A. Rhem, Knowledge Management in Practice. Auerbach Publications, 2016.

[45] S. Zyngier, F. Burstein, and J. McKay, "The Role of Knowledge Management Governance in the Implementation of Strategy," Syst. Sci. 2006. HICSS '06. Proc. 39th Annu. Hawaii Int. Conf., vol. 7, no. C, p. $152 \mathrm{c}-152 \mathrm{c}, 2006$.

[46] A. Kaiser, "An enhanced theory of learning including learning from the future," in Proceedings of the Forty-Ninth Annual Hawaii International Conference on System Sciences (HICSS-49), 2016.

[47] W. H. Starbuck, "Organizational learning and unlearning," Learn. Organ., vol. 24, no. 1, pp. 3038, 2017.

[48] E. W. K. Tsang, "How the concept of organizational unlearning contributes to studies of learning organizations," Learn. Organ., vol. 24, no. 1, pp. 39-48, 2017.

[49] T. Grisold, A. Kaiser, and J. Hafner, "Unlearning before creating new knowledge: A cognitive process," in Proceedings of the Fiftieth Annual Hawaii International Conference on System Sciences (HICSS-50), 2017.

[50] D. Zell, "Organizational Change as a Process of Death, Dying, and Rebirth," J. Appl. Behav. Sci., vol. 39, no. 1, pp. 73-96, Mar. 2003.

[51] S. R. Clegg, M. Kornberger, and C. Rhodes, "Learning/Becoming/Organizing," Organization, vol. 12, no. 2, pp. 147-167, 2005. 